PREFACE

\title{
Long-term studies of the marine ecosystem along the west
} Antarctic Peninsula

Hugh W Ducklow

The Ecosystems Center, MBL

Woods Hole, MA 02543

hducklow@mbl.edu 
Articles in this volume focus on longer-term studies of the marine ecosystem of the continental shelf west of the Antarctic Peninsula, principally by the Palmer, Antarctica LongTerm Ecological Research project (Ross et al., 1996; Ducklow et al., 2007). There is a rich history of oceanographic and ecological research in the Bellingshausen Sea region and on the continental shelf dating back to the 19th and early 20th centuries (El-Sayed, 1996). The modern era of scientific research started with the British Discovery Investigations of 1925-37 (Hardy, 1967), and included classic studies of phytoplankton (Hart, 1934) and krill (Marr, 1962). Hart's report presciently suggested primary producers could be limited by iron availability. El-Sayed (1996) dissects the subsequent history of oceanographic research up to the advent of the Southern Ocean GLOBEC (Hofmann et al., 2001; Hofmann et al., 2004) and JGOFS (Anderson and Smith Jr., 2001) programs. The period from the 1970’s to the mid-90's was dominated by expeditionary and process-level studies of particular regions and processes extending over a few seasons to a few years at most. The Research on Antarctic Coastal Ecosystem Rates (RACER) Program (Huntley et al., 1991; Karl, 1991) is the outstanding example of this mode of research, having focused on determination of key rate processes as a new approach to understanding ecosystem dynamics (Karl et al., 1991a; Karl et al., 1991b). RACER was a direct predecessor and major influence on Palmer LTER, GLOBEC and JGOFS. What was lacking in Antarctic waters, as in most other regions and ocean provinces were sustained, long-term observations of a variety of ocean properties and rates, conducted in the context of hypothesis-driven, experimental science (Ducklow et al., 2008a). The creation of the US LTER Network in 1980 (Magnuson, 1990) made this possible.

Palmer LTER was started in 1990, based on the hypothesis that biological processes in the Antarctic marine environment are strongly affected by physical factors, particularly the 
annual advance and retreat of sea ice (Smith et al., 1995). A key early development was creation of a fixed sampling grid of $~ 50$ hydrographic stations oriented along the axis of the Peninsula (Figure 1) and extending from the nearshore region of persistent pack ice across the continental shelf into the open sea influenced by the Antarctic Circumpolar Current (Waters and Smith, 1992). To date, Palmer LTER has conducted sixteen annual oceanographic cruises in the Austral summer (January-February; Table 1). Most sampling within the grid is limited by shiptime constraints to the 200 to 600 lines shown in Figure 1. The principal objective of each midsummer cruise is conducting a comprehensive sequence of core measurements at each station. The current listing of core measurements may be accessed at http://pal.lternet.edu/publications/documents/protocols/. The sampling grid addresses multiple spatial scales and permits repeated sampling over seasonal to annual time scales, covering short and long-term ecological phenomena. The grid unifies the measurement components and facilitates data integration. This volume reports on the first decade of cruises and includes the first systematic analyses at the grid scale. The cruise-derived data comprise annual snapshots of midsummer conditions. Satellite observations of ocean color and sea ice concentration provide seasonal and year-round coverage, respectively, in which the summer observations are embedded.

Palmer LTER investigators adopted multivariate statistical approaches to analyze the three-dimensional array of measurements $(\mathrm{X}, \mathrm{Y}, \mathrm{T})$ obtained from satellite imagery and on the midsummer cruises. The paper by Martinson et al. (2008) outlines the Empirical Orthogonal Function (EOF) approach used herein by Smith et al. (2008), Martinson et al. (2008), Stammerjohn et al. (2008), Vernet et al. (2008) and Ross et al. (2008) to analyze the timevarying spatial distributions of properties and processes within the Palmer LTER grid. Smith et al. (2008) report on distributions and interannual variability of phytoplankton pigments derived 
from SeaWiFS for 1997-2004. Their analyses extend $400 \mathrm{~km}$ seaward beyond the nominal sampling grid to encompass the Permanently Open Ocean Zone beyond the ACC, and also cover the entire Peninsula, thus providing a large-scale context for other observations (Figure 1 in Smith et al. 2008). Smith et al. demonstrate considerable interannual and regional variability in the size of the annual phytoplankton bloom. The bloom is generally initiated offshore in association with the Antarctic Circumpolar Current Front and not necessarily with the retreating ice edge. Montes-Hugo et al. (2008) also used SeaWiFS data (1997-2006) in conjunction with in situ data to generate a time series of phytoplankton size structure. They found that transitions in the size composition of the phytoplankton community were associated with changes in ENSO state, mirroring variability in other properties (see below).

The paper by Stammerjohn et al. (2008) utilizes satellite microwave data to derive measurements of sea ice concentration over a 1000 x $400 \mathrm{~km}$ region along the Peninsula (within the larger study region of Smith et al. 2008; see Figure 1 of Stammerjohn et al. 2008). Stammerjohn et al. (2008) define the covariability of sea ice, climate and ecosystem properties and identify different ice-ocean marine habitats based on the advance, retreat, duration and persistence of sea ice in different areas along the Peninsula. Interannual variations in the seasonality of sea ice-defined habitats are driven by ENSO and Southern Annular Mode (SAM)associated variations in local winds. Longer-term trends in declining sea ice duration are associated with enhanced warming in the late autumn and early winter seasons of sea ice formation and advance. Sea ice is an important, though still poorly-sampled and not wellunderstood habitat for primary producers and consumers (the sea ice microbial community), as well as a key physical factor influencing biological processes in open water. In their paper Fritsen et al. (2008) explore 10-fold differences in biomass (chlorophyll) in sea ice in late winter 
2001 and 2002. The timing of sea ice formation (June 2001 and April 2002) is proposed as a key factor regulating differences in accumulated biomass. The atmosphere-ocean-ice-biomass coupling is a mechanism possibly generating longer-period cycles in upper trophic levels characteristic of the Antarctic marine ecosystem.

Martinson et al. (2008) provide analysis of physical oceanographic properties (heat, salt) and define the three distinct, bathymetrically-defined regions shown in Figure 1. They also quantify a heat flux of $\sim 28 \mathrm{~W} \mathrm{~m}^{-2} \mathrm{a}^{-1}$ associated with flooding onto the shelf of warm, Upper Circumpolar Deep Water. Variations in UCDW upwelling are driven by the state of ENSO and strength of the SAM, with La Niña and +SAM enhancing the heat flux. This heat flux is the proximate cause of sea ice and glacier melting in the region.

ENSO- and SAM-forced variability that is seen in the LTER study region also impacts on the physical and ecological characteristics of the broader Southern Ocean. Meredith et al. (2008) examined the roles of ENSO and the SAM in determining interannual changes in sea surface temperature around South Georgia, and showed that both fast atmospheric teleconnections and slower oceanic (advective) teleconnections are important. The phasing between these is important for sustaining the anomalies in surface temperature as they propagate across the South Pacific and into the Atlantic. As part of this, rapid atmospheric teleconnections imprint ENSO and SAM signals on the ocean surface immediately west of the Peninsula, offering an additional (more direct) mechanism for coupled climate modes to impact the regional ecosystem, and the ocean downstream. Accordingly, Meredith et al. hypothesize that variability in krill stocks around South Georgia is derived from ENSO- and SAM-forced variations in the advection of krill populations from the Peninsula downstream in the ACC. 
Vernet et al. (2008) and Ross et al. (2008) each analyze twelve year time series of in situ biological measurements made within the central LTER grid (200-600 lines of Figure 1). Vernet et al. define spatial patterns and interannual variations in rates of primary production derived from 24 -hour ${ }^{14} \mathrm{C}$ incubations. Primary production averaged $\sim 60 \mathrm{Mol} \mathrm{C} \mathrm{m}^{-2} \mathrm{~d}^{-1}$ in the grid during January-February 1995-2006. There is a 5-6 year cycle in primary production rates, associated with ENSO forcing of sea ice seasonality. Late sea ice retreat enhanced summer primary production. The numerically dominant macro- and mesozooplanktonic species $>2 \mathrm{~mm}$ captured in net tows over 1993-2004 included euphausiids (Euphausia superba, Thysanoëssa macrura; and Euphausia crystallorophias), the shelled pteropod Limacina helicina, and the salp, Salpa thompsoni (Ross et al. 2008). There were both common (e.g., north-south abundance gradients) and taxon-specific features (e.g., inshore to offshore gradients) in their distributions. Like sea ice, plant pigments and primary production, interannual anomalies in abundance and distributions responded to anomalies in the ENSO cycle, suggesting causal connections among these variables. Time-series sediment traps offer a year-round window into water column processes not directly observable from satellites. Ducklow et al. (2008b) report on the 14-year series of sedimentation fluxes captured in a 170-meter deep trap in the Palmer region (Figure 1). Sedimentation approximating export from the surface layer is strongly periodic with $\sim 75 \%$ of the annual flux exported during an early-summer pulse. Neither the timing nor magnitude of the pulses are directly related to timing of sea ice or phytoplankton blooms, an indication of the complexity of processes responsible for exporting production into the deep sea. Ducklow et al. show that the annual flux event has advanced by about 40 days later since 1993.

The southern area of the LTER sampling grid is in Marguerite Bay, the focus of the Rothera Oceanographic and Biological Time-Series (RaTS) station of the British Antarctic 
Survey at Rothera Station on Adelaide Island (Figure 1). Clarke et al. (2008) reports on eight years of biological and physical observations that extend year-round with weekly resolution. Like other properties already mentioned, the RaTS observations exhibit interannual variability in the same spectral range as ENSO, enforcing the importance of this climate driver in the region. Clarke et al. (2008) demonstrate that UCDW is present even at this inshore location, pointing up the magnitude of irrigation of the shelf ecosystem with offshore waters. Wallace et al. (2008) investigated in detail the shorter-term processes of coastal upwelling and downwelling driven by local winds, and internal tides, that may contribute to the injection of UCDWat the RaTS site. Diurnal internal tides were detected despite the location being poleward of the critical latitude for their generation. The near-coastal location, rough bottom topography and local wind forcing are probably causes of these important physical processes influencing biological productivity in the region.

A key conclusion emerging from analysis of these decade-long observations is the strong teleconnection in the Peninsula region with ENSO variability and its interaction with SAM. It has been hypothesized that anthropogenic warming may generate a more persistent El Niño state (Meehl et al., 2000; Wang and Schimel, 2003) and that the Southern Hemisphere ozone hole intensifies the positive SAM state (Thompson and Solomon, 2002). Better understanding of regional climate, physical oceanographic and ecosystem responses to anomalies in these climate modes will help us to predict responses of the Antarctic marine ecosystem to anthropogenic climate change. Such understanding requires, as one building block, continued time series observations and sustained experimental studies at the interannual and regional scale. Such studies can only be analyzed efficiently if the resulting data and attendant metadata are easily available, accessible and well-cared for. In the concluding paper in this volume, Baker and 
Chandler (2008) discuss evolution in the oceanographic community from simple data storage and provision to interdisciplinary information management, emphasizing the demands of increasing volumes of data, more multidisciplinary and interdisciplinary data types and increased collaboration.

\section{Acknowledgements.}

Observations reported in this volume were supported by NSF Grants OPP-90-11927 and OPP96-32763 to the University of California-Santa Barbara and OPP-02-17282 to the Virginia Institute of Marine Science. We are grateful to the many referees who contributed time and expertise to review and greatly improve these papers.

\section{References.}

Anderson, R.F., Smith Jr., W.O., 2001. The US Southern Ocean Joint Global Ocean Flux Study: Volume Two. Deep Sea Research II 48, 3883-3889.

Baker, K.S., Chandler, C.L., 2008. Ocean Informatics: Information Management in Practice. Deep Sea Research II 55, 000-000.

Clarke, A., Meredith, M.P., Wallace, M.I., Brandon, M.A., Thomas, D.N., 2008. Seasonal and interannual variability in temperature, chlorophyll and macronutrients in northern Marguerite Bay, Antarctica. Deep Sea Research II 55, 000-000.

Ducklow, H.W., Baker, K., Martinson, D.G., Quetin, L.B., Ross, R.M., Smith, R.C., Stammerjohn, S.E., Vernet, M., Fraser, W., 2007. Marine ecosystems: The West Antarctic Peninsula. Philosophical Transactions of the Royal Society of London B 362, 67-94. 
Ducklow, H.W., Doney, S.C., Steinberg, D.K., 2008a. Long-term and Time Series Observations. Annual Review of Marine Science 1, 000-000.

Ducklow, H.W., Erickson, M., Kelly, J., Smith, R.C., Stammerjohn, S.E., Vernet, M., Karl, D.M., 2008b. Particle export from the upper ocean over the continental shelf of the west Antarctic Peninsula: A long-term record, 1992-2006. . Deep Sea Research II 55, 000-000.

El-Sayed, S.Z., 1996. Historical perspective of research in the Antarctic Peninsula region. In: Ross, R.M., Hofmann, E.E., Quetin, L.B. (Eds.), Foundations for Ecological Research West of the Antarctic Peninsula. American Geophysical Union, Washington, DC, pp. 113.

Fritsen, C.H., Memmott, J., Stewart, F.J., 2008. Inter-annual sea ice dynamics and micro-algal biomass in winter pack ice of Marguerite Bay, Antarctica. Deep Sea Research II 55, 000000.

Hardy, A., 1967. Great Waters. Collins, London.

Hart, T.J., 1934. On the phytoplankton of the south-west Atlantic and the Bellingshausen Sea, 1929-31. Discovery Reports 8, 1-268.

Hofmann, E.E., Klinck, J.M., Costa, D.P., Daly, K.L., Torres, J.J., Fraser, W.R., 2001. U. S. Southern Ocean Global Ocean Ecosystems Dynamics Program. Oceanography 15, 64-74.

Hofmann, E.E., Wiebe, P.H., Costa, D.P., Torres, J.J., 2004. An overview of the Southern Ocean Global Ocean Ecosystems Dynamics program. Deep Sea Research II 51, 1921-1924.

Huntley, M.E., Karl, D.M., Niiler, P.P., Holm-Hansen, O., 1991. Research on Antarctic coastal ecosystem rates (RACER): an interdisciplinary field experiment. Deep-Sea Research 38, 911-941. 
Karl, D.M., 1991. RACER - Research on Antarctic coastal ecosystem rates - preface, Part A-Oceanographic Research Papers. Deep-Sea Research 38, R5-R7.

Karl, D.M., Holm-Hansen, O., Taylor, G.T., Tien, G., Bird, D.F., 1991a. Microbial biomass and productivity in the western Bransfield Strait, Antarctica during the 1986-87 austral summer. Deep-Sea Research 38, 1029-1055.

Karl, D.M., Tilbrook, B.D., Tien, G., 1991b. Seasonal coupling of organic matter production and particle flux in the western Bransfield Strait, Antarctica. Deep-Sea Research 38, 10971126.

Magnuson, J.J., 1990. Long-term ecological research and the invisible present. BioScience 40 (7), 495-501.

Marr, J.W.S., 1962. The natural history and geography of the Antarctic krill (Euphausia superba Dana). Discovery Reports 32, 33-464.

Martinson, D.G., Stammerjohn, S.E., Smith, R.C., Iannuzzi, R.A., 2008. Palmer, Antarctica, Long-Term Ecological Research program first 12 years: physical oceanography, spatiotemporal variability. Deep Sea Research II 55, 000-000.

Meehl, G.A., Washington, W.M., Arblaster, J.M., Bettge, T.W., Strand, W.G., 2000. Anthropogenic Forcing and Decadal Climate Variability in Sensitivity Experiments of Twentieth- and Twenty-First-Century Climate. Journal of Climate 13, 3728-3744.

Meredith, M.P., Murphy, E.J., Hawker, E.J., King, J.C., Wallace, M.I., 2008. On the interannual variability of ocean temperatures around South Georgia, Southern Ocean: forcing by El Niño/Southern Oscillation and the Southern Annular Mode. Deep Sea Research II 55, 000-000. 
Montes-Hugo, M.A., Vernet, M., D. Martinson, Smith, R.C., Iannuzzi, R., 2008. Variability on Phytoplankton Size Structure in the Western Antarctic Peninsula (1997-2006). Deep-Sea Research II 55, 000-000.

Ross, R.M., Hofmann, E.E., Quetin, L.B. (Eds.), 1996. Foundations for Ecological Research West of the Antarctic Peninsula. AGU Antarctic Research Series American Geophysical Union, Washington, DC.

Ross, R.M., Quetin, L.B., Martinson, D.G., Iannuzzi, R.J., Stammerjohn, S., Smith, R.C., 2008. Palmer LTER: Patterns of Distribution of Five Dominant Zooplankton Species in the Epipelagic Zone West of the Antarctic Peninsula, 1993 - 2004. Deep Sea Research II 55, 000-000.

Smith, R.C., Baker, K.S., Fraser, W.R., Hofmann, E.E., Karl, D.M., Klinck, J.M., Quetin, L.B., Prezelin, B.B., Ross, R.M., Trivelpiece, W.Z., Vernet, M., 1995. The Palmer LTER: A long-term ecological research program at Palmer Station, Antarctica. Oceanography 8, 77-86.

Smith, R.C., Martinson, D.G., Stammerjohn, S.E., Iannuzzi, R.A., Ireson, K., 2008. Bellingshausen and Western Antarctic Peninsula Region: Pigment biomass and sea ice spatial/temporal distributions and interannual variability. Deep Sea Research II 55, 000000.

Stammerjohn, S.E., Martinson, D.G., Smith, R.C., Iannuzzi, R.A., 2008. Sea Ice in the Western Antarctic Peninsula Region: Spatio-Temporal Variability from Ecological and Climate Change Perspectives. Deep Sea Research II 55, 000-000. 
Thompson, D.W.J., Solomon, S., 2002. Interpretation of Recent Southern Hemisphere Climate Change. Science 296, 895-899.

Vernet, M., Martinson, D.G., Iannuzzi, R.A., Stammerjohn, S.E., Kozlowski, W., Sines, K., Smith, R.C., Garibotti, I., 2008. Primary Production within the Sea Ice Zone west of the Antarctic Peninsula. Deep Sea Research II 55, 000-000.

Wallace, M.I., Meredith, M.P., Brandon, M.A., Sherwin, T.J., Dale, A., Clarke, A., 2008. On the characteristics of internal tides and coastal upwelling behaviour in Marguerite Bay, west Antarctic Peninsula. Deep Sea Research II 55, 000-000.

Wang, G., Schimel, D., 2003. Climate change, climate modes, and climate impacts. Annual Review of Environment and Resources 28, 1-28.

Waters, K.J., Smith, R.C., 1992. Palmer LTER: A sampling grid for the Palmer LTER program. Antarctic Journal of the United States 27, 236-239. 
Table 1. Palmer LTER Cruise Summary Information 1990-2014.

\begin{tabular}{|c|c|c|c|c|c|c|c|}
\hline Cruise & Vessel* & Begin & End & \# days & Year & Lines & Chief Sc \\
\hline & PD & 7-Nov & 21-Nov & 15 & 1991 & $600-700$ & Quetin \\
\hline \multirow[t]{2}{*}{ PAL-1 } & PD & 5-Jan & 8-Feb & 35 & 1993 & $200-600$ & Quetin \\
\hline & NBP & 25-Mar & 15-May & 52 & 1993 & $200-600$ & Ross \\
\hline \multirow[t]{2}{*}{ ICE-1 } & PD & 29-Aug & 25-Sep & 28 & 1993 & $200-600$ & Quetin \\
\hline & PD & 8-Oct & 5-Nov & 29 & 1993 & $200-600$ & Prezelin \\
\hline PAL-2 & PD & 11-Jan & 7-Feb & 28 & 1994 & $300-600$ & Ross \\
\hline PAL-3 & PD & 7-Jan & 8-Feb & 33 & 1995 & $200-600$ & Smith \\
\hline PAL-4 & PD & 8-Jan & $10-F e b$ & 34 & 1996 & $200-600$ & Vernet \\
\hline PAL-5 & PD & 11-Jan & $13-F e b$ & 34 & 1997 & $200-600$ & Ross \\
\hline PAL-6a & $\mathrm{AJ}$ & 13-Jan & 24-Jan & 11 & 1998 & 600 & Quetin \\
\hline PAL-6b & LMG & 28-Jan & 13-Feb & 16 & 1998 & $200-600$ & Karl \\
\hline PAL-7 & LMG & 8-Jan & $12-\mathrm{Feb}$ & 36 & 1999 & $200-600$ & Ross \\
\hline ICE-2 & NBP & 15-Jun & 11-Jul & 27 & 1999 & $200 \& 600$ & Smith \\
\hline PAL-8 & LMG & 8-Jan & 1-Feb & 25 & 2000 & $200-600$ & Vernet \\
\hline PAL-9 & LMG & 5-Jan & 31-Jan & 27 & 2001 & $200-600$ & Ross \\
\hline ICE-3 & NBP & 11-Sep & 22-Oct & 42 & 2001 & $\star \star \star \star .100$ & Smith \\
\hline PAL-10 & LMG & 6-Jan & 28-Jan & 23 & 2002 & $200-600$ & Ross \\
\hline PAL-11 & LMG & 5-Jan & 2-Feb & 28 & 2003 & $200-600$ & Ross \\
\hline PAL-12 & LMG & 7-Jan & 2-Feb & 26 & 2004 & $200-600$ & Ducklow \\
\hline PAL-13 & LMG & 4-Jan & 2-Feb & 29 & 2005 & $200-600$ & Ducklow \\
\hline PAL-14 & LMG & 7-Jan & 5-Feb & 29 & 2006 & $200-600$ & Quetin \\
\hline PAL-15 & LMG & 7-Jan & 7-Feb & 31 & 2007 & $100-600$ & Ducklow \\
\hline PAL-16 & LMG & 5-Jan & 4-Feb & 28 & 2008 & $100-600$ & Quetin \\
\hline PAL-17 & LMG & TBA & TBA & 28 & 2009 & $-100-600$ & Martinson \\
\hline PAL-18 & LMG & TBA & TBA & 28 & 2010 & $-100-600$ & TBA \\
\hline PAL-19 & LMG & TBA & TBA & 28 & 2011 & $-100-600$ & TBA \\
\hline PAL-20 & LMG & TBA & TBA & 28 & 2012 & $-100-600$ & TBA \\
\hline PAL-21 & LMG & TBA & TBA & 28 & 2013 & $-100-600$ & TBA \\
\hline PAL-22 & LMG & TBA & TBA & 28 & 2014 & $-100-600$ & TBA \\
\hline
\end{tabular}


Figure 1. Palmer LTER study area along the west Antarctic Peninsula. The black dots are hydrographic lines $20 \mathrm{~km}$ apart in the cross-shelf direction and $100 \mathrm{~km}$ apart alongshore. The core study region encompassing the 200-600 grid lines has been occupied each January 19932008. The solid black and heavy grey lines identify the three bathymetrically-defined watermass regions (left to right, Slope-Shelf-Coastal). P: Palmer Station on Anvers Island; R: Rothera Station on Adelaide Island; MB, Marguerite Bay; ST, sediment trap mooring. The shaded bathymetry (white $>750 \mathrm{~m}$, light-grey, $450-750 \mathrm{~m}$, dark-grey $<450 \mathrm{~m}$. Contours at the shelf break are greater than or equal to $1500 \mathrm{~m}$ at $750 \mathrm{~m}$ intervals.

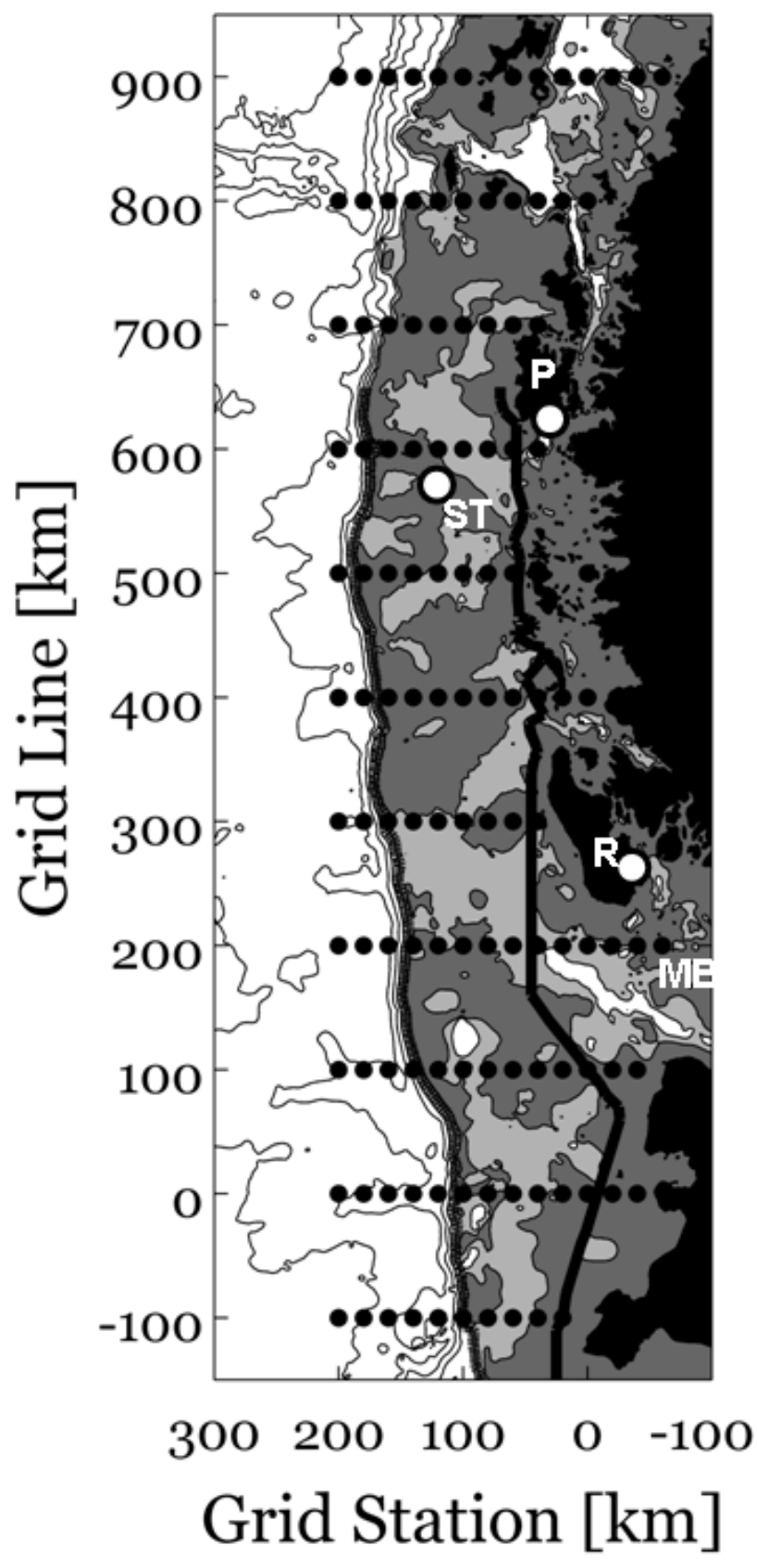

